\title{
NAD and NADP L-Glutamate Dehydrogenase Activity and Ammonium Regulation in Aspergillus nidulans
}

\author{
By J. R. KINGHORN AND J. A. PATEMAN \\ Department of Genetics, University of Glasgow, Glasgow, GI I ${ }_{5}^{J S}$
}

(Received I4 December 1972)

SUMMARY

Mutants, designated $g d h A$, deficient in NADP-glutamate dehydrogenase activity grow poorly using inorganic nitrogen but normally using amino acids as nitrogen sources. The $g d h A$ mutants are not repressed by ammonia for a number of enzyme and uptake systems. The nine gdhA mutations are allelic and located in linkage group III; $g d h A I$ is recessive in the heterozygous diploid with respect to both NADP glutamate dehydrogenase activity and ammonium regulation.

Mutants, designated $g d h B$, deficient in NAD-glutamate dehydrogenase activity are unable to utilize L-glutamate as a carbon source, but can utilize inorganic and organic nitrogen as nitrogen sources. The four $g d h B$ mutations are allelic, located in linkage group $I V$, and $g d h B I$ is recessive in the heterozygous diploid. The $g d h B$ mutants are repressed for the ammonium regulated systems which are not repressed in $g d h A$ mutants.

\section{INTRODUCTION}

Aspergillas nidulans can synthesize two L-glutamate dehydrogenases. L-Glutamate: NADP oxidoreductase EC. I.4.I.4 (NADP-GDH) has an aminating function and maximal activity is found in cells utilizing inorganic nitrogen and minimal activity in cells utilizing L-glutamate (Pateman, I 969). L-Glutamate: NAD oxidoreductase EC. I . 4 I I 2 (NAD-GDH) has a deaminating function and optimal activity is found in cells utilizing L-glutamate as the sole carbon source (Kinghorn \& Pateman, I972). A similar situation is known to occur in a number of other higher fungi (LéJohn, I97I).

Grenson \& Hou (1972) have described a mutant in Saccharomyces cerevisiae which lacks NADP-GDH activity and is abnormal with respect to the regulation by ammonium of the general amino acid permease. Mutations in a number of loci in Aspergillus nidulans can affect the regulation of a number of systems by ammonium. These systems include nitrate reductase (Pateman \& Cove, 1967), hypoxanthine dehydrogenase (Scazzocchio \& Darlington, I968), extracellular protease (Cohen, 1972), acetamidase and formamidase (Hynes \& Pateman, 1970 $a, b$ ), glutamate uptake (Kinghorn \& Pateman, 1972; Pateman \& Kinghorn, unpublished) and urea uptake (Dunn \& Pateman, 1972). Arst \& Cove (1969) found that mutation in two loci meaA and meaB resulted in resistance to methylamine and derepression for many ammonium repressed systems. Cohen (1972) isolated a mutant $x p r D I$ which was derepressed for extracellular protease release and other systems. J. Pateman and others (unpublished) have isolated other classes of derepressed mutants, DER3 and amrAI, which have ammonium transport abnormalities. We report the level of NADP-GDH activity in the various classes of ammonium derepressed mutants. We also describe some properties of mutants deficient in either NADP-GDH or NAD-GDH activity, with particular reference to ammonium regulation.

\section{METHODS}

Materials. All reagents were obtained from commercial sources and were used without further purification. 
Media and supplements. Medium used for genetic analysis was essentially that described by Pontecorvo, Roper, Hemmons, MacDonald \& Bufton (1953). Nitrogen-less minimal medium ( $-\mathrm{N}$ medium) (Cove, I966), and carbon- and nitrogen-less minimal medium ( $-\mathrm{CN}$ medium) were used. The nitrogen and carbon sources used in media were kept as sterile stock solutions at I $\mathrm{M}$.

Growth of mycelium for enzyme assays. Cells were grown in shaken flask culture at $30^{\circ} \mathrm{C}$, harvested and extracted by grinding in a cold mortar essentially as described by Cove (I966). Mycelium was grown on $-\mathrm{N}$ medium containing $0.15 \%$ Casamino acids plus 5 mM-ammonium tartrate for $\mathrm{I} 5 \mathrm{~h}$ before transfer to treatment media for $5 \mathrm{~h}$. For maximum NADP-GDH activity the treatment medium was $-\mathrm{N}$ medium plus 5 mM-ammonium tartrate. For maximum NAD-GDH activity the treatment medium was $-\mathrm{CN}$ medium plus IOO mM-glutamate. The mycelium was pressed dry, using paper towels, and weighed. Yields were usually 5 to $8 \mathrm{~g} / \mathrm{l}$ medium.

L-Glutamate dehydrogenase. NAD-GDH and NADP-GDH were assayed following the reductive amination of $\alpha$-oxoglutarate in the presence of ammonia and reduced NAD or NADP. The initial reaction velocity was estimated from the change in optical density at $340 \mathrm{~nm}$ in a Unicam SP 800 spectrophotometer. The reaction mixture for the NADP-GDH assay was: $0.4 \mathrm{M}-\mathrm{NH}_{4} \mathrm{Cl}$ in $0.05 \mathrm{M}$-phosphate buffer $(\mathrm{pH} 7.75), 0.4 \mathrm{ml} ; 0.2 \mathrm{M}$ - $\alpha$-ketoglutarate in $0.05 \mathrm{M}$-phosphate buffer $(\mathrm{pH} 7.75), 0.2 \mathrm{ml}$; reduced NADP $(2 \mathrm{mg} / \mathrm{ml}), 0.2 \mathrm{ml} ; 0.05 \mathrm{M}-$ phosphate buffer ( $\mathrm{pH} 7 \cdot 75$ ), $2 \mathrm{ml}$; enzyme extract (I to $2 \mathrm{mg}$ protein $/ \mathrm{ml}$ ), $0 \cdot 2 \mathrm{ml}$. The reaction mixture for the NAD-GDH was: $0.4 \mathrm{M}-\mathrm{NH}_{4} \mathrm{Cl}$ in $0.05 \mathrm{M}$-phosphate buffer $(\mathrm{pH} 8.0$ ), $0.4 \mathrm{ml} ; 0.2 \mathrm{M}$ - $\alpha$-ketoglutarate in $0.05 \mathrm{M}$-phosphate buffer $(\mathrm{pH} 8.0), 0.2 \mathrm{ml}$; reduced NAD $(2 \mathrm{mg} / \mathrm{ml}), 0.2 \mathrm{ml} ; 0.05 \mathrm{M}$-phosphate buffer $(\mathrm{pH} 8.0)$ with $0 . \mathrm{I} \mathrm{mM}-\beta$-mercaptoethanol and 0.5 mM-EDTA. The assay temperature in both cases was $37^{\circ} \mathrm{C}$ and the results expressed as nanomole substrate transformed $/ \mathrm{min} / \mathrm{mg}$ protein.

Plate tests for ammonium derepression. (I) Nitrate reductase: ammonium, by repressing nitrate reductase synthesis, protects the wild-type against chlorate toxicity; poor growth on $-\mathrm{N}$ medium plus $100 \mathrm{mM}-\mathrm{KClO}_{3}$ plus Io mM-ammonium indicates derepression of nitrate reductase (Arst \& Cove, I969). (2) Xanthine dehydrogenase: a green-spored wildtype develops yellow conidia in the presence of 2-thioxanthine due to the action of xanthine dehydrogenase. Ammonium prevents the development of yellow conidia by repressing xanthine dehydrogenase. The production of yellow conidia by a genotypically green-spored strain grown on $-\mathrm{N}$ medium plus $0.5 \mathrm{~mm}$-thioxanthine plus $10 \mathrm{~mm}$-ammonium, indicates derepression of xanthine dehydrogenase (Scazzocchio \& Darlington, I968). (3) Extracellular protease: ammonium derepression of protease release is indicated by a milk clearing halo around a colony growing on turbid - $\mathrm{N}$ medium plus milk plus Io mM-ammonium (Cohen, 1972).

Plate test for methylamine resistance. Wild-type cells will not grow on $-\mathrm{N}$ medium plus Ioo mM-methylamine chloride; methylamine resistant strains grow well (Arst \& Cove, 1969).

Growth of mycelium for uptake assays. After growth in shaken flasks at $25^{\circ} \mathrm{C}$ for $\mathrm{I} 6$ to $20 \mathrm{~h}$ on $-\mathrm{N}$ medium plus $0.15 \%$ Casamino acids, cells were harvested and transferred to $-\mathrm{N}$ medium + $10 \mathrm{~mm}$-ammonium tartrate for $4 \mathrm{~h}$ at $25^{\circ} \mathrm{C}$. In the latter treatment, cells were transferred five times during the $4 \mathrm{~h}$ period to maintain the ammonia concentration close to the original value. Finally, the cells were harvested and assayed.

L-Glutamate and thiourea uptake assays. When grown under the conditions described above, Aspergillus nidulans is largely in the form of small colonies less than I $\mathrm{mm}$ in diameter. These colonies can be kept in suspension by shaking and samples withdrawn quanti- 
tively from the suspension. After growth and subsequent transfer to treatment medium for $5 \mathrm{~h}, \mathrm{I} \mathrm{g}$ fresh weight of the cells is resuspended in $50 \mathrm{ml}$ of $-\mathrm{N}$ medium plus L-glutamate or thiourea in a $250 \mathrm{ml}$ Erlenmeyer flask in a shaking water bath at $25^{\circ} \mathrm{C}$. To assay L-glutamate uptake the flasks contain $\left[{ }^{12} \mathrm{C}\right] \mathrm{L}$-glutamate and $\left[{ }^{14} \mathrm{C}\right] \mathrm{L}$-glutamate to a final concentration of $100 \mu \mathrm{M}$ and approximately $\mathrm{I} \cdot 0 \mu \mathrm{C}$ radioactivity; for thiourea uptake they contain $\left[{ }^{12} \mathrm{C}\right]$ thiourea and $\left[{ }^{14} \mathrm{C}\right]$ thiourea to a final concentration of $200 \mu \mathrm{M}$ and approximately $3 \cdot 0 \mu \mathrm{C}$ radioactivity. At $2 \mathrm{~min}$ intervals from 2 to $10 \mathrm{~min}, 5 \mathrm{ml}$ aliquots of the cell suspension are filtered with two washes of $\mathrm{I} 0 \mathrm{ml}$ of water, on a Millipore filter. The resultant pad of cells is transferred to $5 \mathrm{ml}$ Bray's scintillation fluid and the radioactivity measured in a Beckman Liquid Scintillation Spectrometer. The rate of uptake of radioactivity into cells is linear for both substances up to Io min. The level of uptake of the two substances in wildtype cells is 20 times higher on $-\mathrm{N}$ medium treatment (derepressed level) than on $-\mathrm{N}$ medium plus Io mM-ammonium tartrate (repressed level). The results are expressed in terms of repressed or derepressed level in mutant cells after treatment on $-\mathrm{N}$ medium with 10 mM-ammonium tartrate.

Strains and genetic analysis. The genetic techniques employed were those described by Pontecorvo et al. (1953) and McCully \& Forbes (1965). The strains used were a biotin auxotroph biI (Glasgow No. 05I) and a biotin and putrescine auxotroph biI puAz (Glasgow No. $017 \mathrm{I}$ ). meaA8 and meaB6 (formerly meaA6) are methylammonium-resistant, ammonium-derepressed mutants (Arst \& Cove, 1969) supplied by Dr H. N. Arst. DER3 is one of a series of ammonium derepressed mutants obtained by J. A. Pateman selecting directly for ammonium derepression of nitrate reductase using a replica plating technique similar to that described by Pateman \& Cove (1967). amrAI was obtained by J. A. Pateman selecting for mutants with poor growth on ammonium as a nitrogen source. $x p r D I$ is an ammonium derepressed mutant obtained by selecting directly for ammonium derepression of extracellular protease production (Cohen, I972) supplied by Dr B. L. Cohen.

Protein determination. All protein determinations were carried out by the procedure of Lowry, Rosebrough, Farr \& Randall (195I).

Selection of NADP-GDH mutants. $N$-methyl- $N^{\prime}$-nitro- $N$-nitrosoguanidine (NTG) treated conidia (Adelberg, Mandel \& Chen, 1965) of bir were spread on $-\mathrm{N}$ medium with $2 \mathrm{~mm}$ urea, biotin and sodium deoxycholate (Mackintosh \& Pritchard, 1963). After incubation, the colonies were replicated on to $-\mathrm{N}$ medium containing biotin and $100 \mathrm{~mm}$-ammonium tartrate. Colonies which failed to grow on the I00 mM-ammonia medium were isolated and cloned by replating for isolated colonies.

Selection of mutants with low NAD-GDH activity. The putrescine technique (Herman \& Clutterbuck, 1966) was used to isolate mutants unable to use L-glutamate as a sole carbon and nitrogen source. Clumps of NTG-treated conidia of bis puAz were inoculated on to solid - NC medium plus biotin, limiting putrescine and with $100 \mathrm{mM}$-L-glutamate as sole carbon and nitrogen source. Sectors showing spidery growth were isolated. A number of these proved to be mutants unable to utilize L-glutamate.

\section{RESULTS}

\section{Isolation and characterization of mutants}

Nine mutants, designated $g d h A I$ to $g d h A g$, were isolated on the basis of sensitivity to high concentrations of ammonium (ammonium-sensitive mutants). Diploids between $g d h A I$ and the other $g d h A$ mutants, and heterokaryons of all possible combinations of $g d h A$ mutants, were made. The mutants were shown to be allelic by their failure to complement in these 
Table I. NADP and NAD-GDH activities in $g d h A, g d h B$ and various classes of ammonium derepressed mutants

The mycelia were grown and treated as described in the Methods section to give the maximum NADP-GDH or NAD-GDH activity

\begin{tabular}{|c|c|c|}
\hline \multirow[b]{2}{*}{ Strain } & \multicolumn{2}{|c|}{ Enzyme activity (nmole $/ \mathrm{min} / \mathrm{mg}$ ) } \\
\hline & NADP-GDH & NAD-GDH \\
\hline Wild-type & 1940 & 1520 \\
\hline$g d h A I$ & $*$ & 1610 \\
\hline$g d h A 2$ & $*$ & 1600 \\
\hline$g d h A_{3}$ & $*$ & 1300 \\
\hline$g d h A 4$ & $*$ & 1490 \\
\hline$g d h A 5$ & 310 & 1590 \\
\hline$g d h A 6$ & 350 & I 210 \\
\hline$g d h A_{7}$ & 320 & 1430 \\
\hline $\operatorname{gdh} A 8$ & 210 & 1630 \\
\hline$g d h A 9$ & 395 & 1690 \\
\hline$g d h A I+$ & 1810 & 1630 \\
\hline$g d h B I$ & I 830 & $*$ \\
\hline$g d h B 2$ & 2015 & * \\
\hline$g d h B_{3}$ & 2010 & * \\
\hline$g d h B 4$ & I 895 & * \\
\hline$g d h B I+$ & I 825 & 1200 \\
\hline meaA8 & 1790 & N.T. \\
\hline meaB6 & 1520 & N.T. \\
\hline$x p r D_{I}$ & I 840 & N.T. \\
\hline$a m r A I$ & 2050 & N.T. \\
\hline $\mathrm{DER}_{3}$ & 1615 & N.T. \\
\hline
\end{tabular}

diploids and heterokaryons. The $g d h A$ locus was assigned to the $\arg B$-galD interval of the III linkage group. The $g d h A$ locus shows $50 \%$ recombination with meaA6 and $24 \%$ with $x p r D I$, which are in the same linkage group.

Four mutants, $g d h B I-g d h B 4$, were isolated, which were unable to utilize L-glutamate as a carbon source. Similarly they were found to be allelic by complementation tests carried out on the heterokaryons. The $g d h B$ locus was assigned to linkage group IV.

\section{Glutamate dehydrogenase activity in gdhA and gdhB mutants}

It can be seen from Table I that $g d h A$ mutations lead to decreased activities of NADPGDH, from zero to $20 \%$ of wild-type, while NAD-GDH is unaffected. The heterozygous diploid $g d h A I /+$ has similar NADP-GDH activity to the haploid $g d h A^{+}$, indicating that the $g d h A I$ mutation is recessive.

Conversely, $g d h B$ mutants have undetectable NAD-GDH activity and wild-type NADGDH levels. The heterozygous diploid $g d h B I /+$ has similar NAD-GDH activity to the haploid $g d h B^{+}$, indicating that the $g d h B r$ mutation is recessive.

The NADP-GDH levels of the wild-type and the derepressed mutants meaA8, meaB6, $x p r D I, a m r A r$ and DER 3 are given in Table $\mathrm{I}$. The only class of derepressed mutants which has low NADP-GDH is the ammonium-sensitive class, the gdhA mutants. 
Table 2. The level of some enzyme and uptake systems which are regulated by ammonium in the gdhA and gdhB mutants

Ammonium repression of xanthine dehydrogenase, nitrate reductase and extracellular protease was determined by the plate tests given in Methods. Ammonium repression of L-glutamate uptake was determined by L-glutamate uptake assays. Ammonium repression of thiourea uptake was determined by thiourea uptake assays and the thiourea plate test given in Methods.

\begin{tabular}{|c|c|c|c|c|c|}
\hline Strain & $\begin{array}{c}\text { Xanthine } \\
\text { dehydrogenase }\end{array}$ & $\begin{array}{l}\text { Nitrate } \\
\text { reductase }\end{array}$ & $\begin{array}{l}\text { Extracellular } \\
\text { protease }\end{array}$ & $\begin{array}{c}\text { Glutamate } \\
\text { uptake }\end{array}$ & $\begin{array}{r}\text { Thioure } \\
\text { uptake }\end{array}$ \\
\hline Wild-type & $\mathbf{R}$ & $\mathbf{R}$ & $\mathbf{R}$ & $\mathbf{R}$ & $\mathbf{R}$ \\
\hline$g d h A I$ & $\mathrm{D}$ & D & $\mathbf{R}$ & D & D \\
\hline$g d h A 2$ & $\mathrm{D}$ & D & $\mathbf{R}$ & D & D \\
\hline $\operatorname{gdh} A 3$ & D & D & $\mathbf{R}$ & D & D \\
\hline$g d h A 4$ & D & D & $\mathrm{R}$ & D & $\mathrm{D}$ \\
\hline$g d h A 5$ & D & D & $\mathrm{R}$ & D & $\mathrm{D}$ \\
\hline$g d h A 6$ & D & D & $\mathbf{R}$ & D & $\mathrm{D}$ \\
\hline$g d h A 7$ & D & $\mathrm{D}$ & $\mathbf{R}$ & D & $\mathrm{D}$ \\
\hline$g d h A 8$ & D & $\mathrm{D}$ & $\mathrm{R}$ & D & D \\
\hline$g d h A 9$ & D & D & $\mathbf{R}$ & D & $\mathrm{D}$ \\
\hline$g d h A I^{\prime}+$ & $\mathrm{R}$ & $\mathrm{R}$ & $\mathbf{R}$ & $\mathbf{R}$ & $\mathbf{R}$ \\
\hline$g d h B I$ & $\mathbf{R}$ & $\mathrm{R}$ & $\mathbf{R}$ & $\mathrm{R}$ & $\mathrm{R}$ \\
\hline$g d h B 2$ & $\mathbf{R}$ & $\mathrm{R}$ & $\mathrm{R}$ & N.T. & N.T. \\
\hline$g d h B_{3}$ & $\mathrm{R}$ & $\mathrm{R}$ & $\mathbf{R}$ & N.T. & N.T. \\
\hline$g d h B_{4}$ & $\mathrm{R}$ & $\mathbf{R}$ & $\mathrm{R}$ & N.T. & N.T. \\
\hline
\end{tabular}

$\mathrm{R}$, System repressed by ammonia; D, system not repressed by ammonia; N.T. not tested.

Table 3. Growth responses of gdhAI and gdhBI mutants on certain nitrogen and carbon sources

\begin{tabular}{|c|c|c|c|c|c|c|c|c|}
\hline \multirow[b]{2}{*}{ Genotypes } & \multicolumn{8}{|c|}{$-\mathrm{N}$ medium (solid) } \\
\hline & $\begin{array}{l}\text { Io mM- } \\
\text { ammonia }\end{array}$ & $\begin{array}{l}10 \mathrm{mM}^{-} \\
\mathrm{NO}_{3}\end{array}$ & $\begin{array}{l}\text { Io mM- } \\
\text { urea }\end{array}$ & $\begin{array}{l}10 \mathrm{mM}-\mathrm{L}- \\
\text { glutamate }\end{array}$ & $\begin{array}{l}\text { ro mM-L- } \\
\text { alanine }\end{array}$ & $\begin{array}{l}\text { Io } \mathrm{mM}-\mathrm{L}- \\
\text { aspartate }\end{array}$ & $\begin{array}{l}\text { I00 mM- } \\
\text { urea }\end{array}$ & $\begin{array}{l}\text { I00 mM- } \\
\text { ammonia }\end{array}$ \\
\hline Wild-type & + & + & + & + & + & + & + & + \\
\hline$g d h A I$ & \pm & \pm & \pm & + & + & + & - & - \\
\hline gdhaAI $1+$ & $\overline{+}$ & $\overline{+}$ & $\overline{+}$ & + & + & + & + & + \\
\hline$g d h B I$ & + & + & + & + & + & + & + & + \\
\hline \multirow[t]{9}{*}{$g d h B I /+$} & + & + & + & + & + & + & + & + \\
\hline & \multicolumn{8}{|c|}{ - $\mathrm{CN}$ medium (solid) } \\
\hline & \multirow{2}{*}{\multicolumn{3}{|c|}{ Genotypes }} & \multicolumn{3}{|c|}{$\begin{array}{l}\text { I00 mM- } \\
\text { glutamate }\end{array}$} & & \\
\hline & & & & $\begin{array}{l}\text { I00 mM- } \\
\text { glutamate }\end{array}$ & $\begin{array}{l}+50 \mathrm{~m} \\
\text { ammon }\end{array}$ & & & \\
\hline & \multicolumn{3}{|c|}{ Wild-type } & + & + & & & \\
\hline & \multicolumn{3}{|c|}{$\begin{array}{l}\operatorname{gdh} A T \\
\text { gdhaAIt }\end{array}$} & \pm & - & & & \\
\hline & \multirow{2}{*}{\multicolumn{3}{|c|}{$\begin{array}{l}\text { gdhaAII+ } \\
\text { gdhBI }\end{array}$}} & + & + & & & \\
\hline & & & & - & - & & & \\
\hline & \multicolumn{3}{|c|}{$g d h B I \mid+$} & + & + & & & \\
\hline
\end{tabular}

+ Normal growth of wild-type; \pm up to $50 \%$ growth of that of wild-type; - extremely poor growth. 


\section{The gdhA mutation and ammonium derepression}

The results given in Table 2 show that $g d h A$ mutations result in the failure of ammonium to repress xanthine dehydrogenase, nitrate reductase, glutamate uptake and urea uptake, but the mutants are repressed for protease. The heterozygous diploid $g d h A I /+$ is repressed for all of these systems. The $g d h B$ mutants are also repressed.

\section{Growth responses of $g d h A$ and $g d h B$ mutants}

Mutation in the $g d h A$ locus results in poor growth on inorganic nitrogen sources. In addition, the $g d h A$ mutants are sensitive to high concentrations of ammonium and grow very poorly in the presence of 100 to $200 \mathrm{mM}$-ammonium or $100 \mathrm{mM}$-urea. With $50 \mathrm{mM}$-L-glutamate as the sole carbon source, the $g d h A$ mutants grow less than the wild-type. $g d h A$ mutants grow very poorly with L-glutamate as the carbon source together with $50 \mathrm{mM}$ ammonium. The heterozygous diploid, $g d h A I /+$, grows like the haploid wild-type in all the test conditions.

The $g d h B$ mutants grow as well as the wild-type on all nitrogen sources. The $g d h B$ mutants grow poorly on L-glutamate as the sole carbon source. The heterozygous diploid, $g d h B I /+$, grows as well as the haploid wild-type with L-glutamate as the sole carbon source.

\section{DISCUSSION}

Aspergillus nidulans produces two types of glutamate dehydrogenase; one form specific for NAD has a degradative deaminating function, the other specific for NADP has a synthetic aminating function. The different in vivo functions of the two enzymes are clearly demonstrated by the conditions which determine the synthesis of the two enzymes and the growth properties of strains carrying mutations at the $g d h A$ and $g d h B$ loci. The synthesis of NADP-GDH in $A$. nidulans is probably regulated by L-glutamate (Pateman, 1969). The synthesis of NAD-GDH in $A$. nidulans is probably regulated by glucose or some metabolite derived from glucose J. R. (Kinghorn \& J. A. Pateman, unpublished). The gdhA mutants, which lack NADP-GDH activity, are unable to utilize inorganic nitrogen efficiently for the synthesis of glutamic acid and require a supplement of amino acid for normal growth. In the presence of the usual carbon sources the synthesis of NAD-GDH does not fully substitute for the lack of NADP-GDH. The gdhA mutants grow poorly when L-glutamate is the sole carbon source, despite the production of NAD-GDH, but this is probably a secondary effect which is discussed below. The $g d h B$ mutants, which lack NAD-GDH activity, can utilize inorganic nitrogen and do not require an amino acid supplement for normal growth. The $g d h B$ mutants are unable to utilize L-glutamate as a carbon source, since the glutamate repressed level of NADP-GDH is insufficient for the deamination of glutamate.

The $g d h A$ mutants are sensitive to high concentrations of ammonium. The reason for this is not clear. It may be connected with the fact that $g d h A$ mutants have a higher intracellular ammonium concentration than the wild-type in the presence of extracellular ammonium or urea. However, some other ammonium derepressed mutants also have high intracellular ammonium pools, but are not ammonium-sensitive (J. A. Pateman and others, unpublished). It is probable that the poor growth of $g d h A$ mutants on L-glutamate as a carbon source is due to the effect of the large amounts of ammonium produced from the glutamate by the NAD-GDH. The $g d h B$ mutants are not sensitive to high concentrations of ammonium.

The $g d h A$ and $g d h B$ loci are probably the structural genes for the NADP-GDH and NAD$\mathrm{GDH}$ enzymes respectively, since no other loci are known at which mutation can result in 
the lack of either activity. In addition to the differences in coenzyme specificity, function, regulation and genetic determination, there is a further important distinction between the two forms of GDH. The $g d h A$ mutants, but not the $g d h B$ mutants, are derepressed for a number of enzyme and uptake systems which are regulated by ammonium. This suggests that the NADP-GDH protein, but not the NAD-GDH protein, plays some role in ammonium regulation. However, NADP-GDH can only be a part of the regulatory system since deficient NADP-GDH is not an essential requirement for the absence of ammonium repression. Five other classes of mutants not repressed by ammonium, $x p r D I$, meaA, meaB, $\mathrm{DER}_{3}$ and $a m r A I$, all have normal NADP-GDH.

Three main possibilities occur to us concerning the relationship between NADP-GDH and ammonium regulation. The first possibility is that NADP-GDH is a multi-functional protein which has catalytic activity and also plays a direct role in either the repression or inhibition, or both, of a number of activities. Mutation in the gdhA locus, the structural gene for NADP-GDH, would result in both abnormal enzyme and control activity. This seems to us at present the most likely explanation. Second, the NADP-GDH protein specified by the $g d h A$ locus has only a catalytic function, but low NADP-GDH activity itself results in metabolic changes, e.g. ammonium pool size, which then result in derepression. There is evidence concerning the relationship between ammonium pool size and ammonium regulation which makes this possibility an unlikely one (J. A. Pateman and others, unpublished). The third possibility is that the $g d h A$ gene specifies a product which has some fundamental but at present unknown regulatory function with respect to a number of metabolic systems. Mutations in the $g d h A$ locus can simultaneously result in repression of NADP-GDH and derepression of other systems. This is an unlikely hypothesis since it requires that there are no structural gene mutants in the total of nine NADP-GDH mutants isolated. Yet structural gene mutants should be the most common class of enzyme-deficient mutants. We are currently making temperature sensitive mutants and looking at the kinetic and electrophoretic properties of the NADP-GDH from $g d h A$ mutants in order to obtain more definitive evidence on this point.

If NADP-GDH is in some sense a regulatory molecule, the amino acid sequence and three-dimensional structure of the protein are obviously of great interest. Nothing is known at present of the amino acid sequence of the NADP-GDH of Aspergillus nidulans. However, the NADP-GDH of Neurospora crassa has been intensively studied by J.R.S. Fincham and co-workers (Fincham, I962; Wootton, Chambers, Taylor \& Fincham, 1973), and structural gene mutants are available which result in known amino acid replacements in the NADPGDH protein. It is not known as yet if the NADP-GDH of $N$. crassa is involved in ammonia regulation, although preliminary work indicates that the urea uptake system in $N$. crassa may be regulated by ammonia (J. A. Pateman, unpublished). It may be that the NADPGDH of $N$. crassa will provide the opportunity to study the effect of known amino acid replacements on the catalytic and regulatory properties of a protein.

The support received by J. A. Pateman from the Australian Universities Grant Commission while part of this work was done in the Flinders University of South Australia is gratefully acknowledged.

J. R. Kinghorn gratefully acknowledges the award of a University of Glasgow Postgraduate Research Studentship. 


\section{REFERENCES}

Adelberg, E. A., Mandel, M. \& Chen, G. C. C. (1965). Optimum conditions for mutagenesis by $N$-methyl$N^{\prime}$-nitro- $N$-nitrosoguanidine in Escherichia coli KI2. Biochemical and Biophysical Research Communications $\mathbf{1 8}, 788-795$.

ARST, H. N. \& COVE, D. J. (1969). Methylammonium resistance in Aspergillus nidulans. Journal of Bacteriology 98, I 284-I 293.

COHEN, B. L. (1972). Ammonium repression of extracellular protease in Aspergillus nidulans. Journal of General Microbiology 71, 293-299.

Cove, D. J. (1966). The induction and repression of nitrate reductase in the fungus Aspergillus nidulans. Biochimica et biophysica acta $\mathrm{Ir}_{3}, 5 \mathrm{I}-56$.

Dunn, E. \& Pateman, J. A. (1972). Urea and thiourea uptake in Aspergillus nidulans. Heredity 29 , I 29.

Fincham, J. R. S. (1962). Genetically determined multiple forms of glutamic dehydrogenase in Neurospora crassa. Journal of Molecular Biology 4, 257.

Grenson, M. \& Hou, C. (1972). Ammonia inhibition of the general amino acid permease and its suppression in NADP-specific glutamate dehydrogenase mutants of Saccharomyces cerevisiae. Biochemical and Biophysical Research Communications 48, 749-756.

Herman, C. \& Clutterbuck, A. J. (I966). A method for selection of auxotrophs by means of 'spidery' growth. Aspergillus Newsletter 7, $13-14$.

Hynes, M. J. \& PAteman, J. A. (1970a). The genetic analysis of regulation of amidase synthesis in Aspergillus nidulans. I. Mutants unable to utilise acrylamide. Molecular and General Genetics ro8, 97-106.

Hynes, M. J. \& PAteman, J. A. (1970 b). The genetic analysis of regulation of amidase synthesis in Aspergillus nidulans. II. Mutants resistant to fluoroacetamide. Molecular and General Genetics 108, I07-I I6.

Kinghorn, J. R. \& PAteman, J. A. (1972). Regulation of glutamate transport in Aspergillus nidulans. Heredity $29, \mathbf{I} 28$.

LÉJoHN, H. B. (197I). Enzyme regulation, lysine pathways and cell wall structures as indicators of major lines of evolution in fungi. Nature, London 23x, 164-168.

Lowry, O. H., Rosebrough, M. J., FARr, J. C. \& Randall, R. J. (I95I). Protein measurement with the Folin phenol reagent. Journal of Biological Chemistry 193, 265-275.

Mackintosh, M. E. \& Pritchard, R. H. (1963). The production and replica plating of micro-colonies of Aspergillus nidulans. Genetical Research, Cambridge 4, 320-322.

MCCully, K.S. \& Forbes, E. (I965). Use of $p$-fluorophenylalanine with master strains of Aspergillus nidulans. Genetical Research, Cambridge 6, 352-359.

Pateman, J. A. (1969). Regulation of the synthesis of glutamic dehydrogenase and glutamine synthetase in micro-organisms. Biochemical Journal $\mathbf{1 \times 5}, 769$.

Pateman, J. A. \& Cove, D. J. (I967). Regulation of nitrate reduction in Aspergillus nidulans. Nature, London 215, I234-I 239.

Pontecorvo, G., Roper, J. A., Hemmons, L. M., MacDonald, K. D. \& Bufton, A. W. J. (I953). The genetics of Aspergillus nidulans. Advances in Genetics 5, I4I-238.

Scazzocchio, C. \& Darlington, A. J. (1968). The induction and repression of the enzymes of purine breakdown in Aspergillus nidulans. Biochimica et biophysica acta $\mathbf{1 6 6 , 5 5 7 - 5 6 8 .}$

Wootton, J. C., Chambers, G. K., Taylor, J. G., \& Fincham J. R. S. (I973). Amino-acid sequence homologies between the NADP-dependent glutamate dehydrogenase of Neurospora and the bovine enzyme Nature New Biology 24r, 42-43. 